\title{
Proximate Composition and Mineral Content of Selected Edible Mushroom Varieties of Bangladesh.
}

\author{
Md. Khurshidul Zahid ${ }^{\text {* }}$, Sagarmay Barua ${ }^{1}$ and S. M. Imamul Haque ${ }^{2}$ \\ Institute of Nutrition and Food Science, University of Dhaka, Dhaka-1000 ${ }^{1}$ \\ Department of Soil, Water and Environment, University of Dhaka, Dhaka ${ }^{2}$.
}

\begin{abstract}
Proximate composition and mineral content of five species of edible mushrooms namely Pleurotus ostreatus, Pleurotus sajor-caju, Pleurotus florida and Pleurotus HK- 51 belonging to the family: Pleurotaceae and genus: Pleurotus and Calocybe indica belonging to the family: Tricholomataceae and Genus: Calocybe have been analyzed.Crude_protein, total lipids, available carbohydrates, dietary fiber and total carbohydrates content in mushrooms were found to be in the ranges of 3.22-4.83, 0.41-1.05, 4.2-6.37, 0.58-1.11 and 4.82-7.48 g per 100g of fresh edible portion(EP) respectively. Moisture, total solids and ash content were found to be in the ranges of 85.95-90.07, 9.93-14.05 and 0.98-2.3 g/100g of fresh EP respectively. Where as total calorie values in mushrooms were found to be in the ranges of $35.51-50.03$ Kcal / 100g fresh EP. The values of Zinc, copper, iron, sodium and potassium content in mushrooms were found to be in the ranges of $0.65-1.24,0.14-0.91,0.94-$ 1.81, 3.18-37.23 and 19.83-197.24 mg/100g of fresh EP respectively while calcium, magnesium, phosphorus and manganese content were in the ranges of $0.12-0.58$, 27.26-51.21, 22.2-62.1 and 0.17-0.53 mg/100g of fresh EP respectively.
\end{abstract}

Key words: Mushroom , Proximate composition , Mineral content .

\section{Introduction:}

Mushrooms are incredibly popular foods in most countries. Edible and medicinal mushrooms are regarded as the ideal health foods. They are well appreciated for their exquisite taste and flavor and are consumed both in the fresh and processed forms ${ }^{1}$.Edible mushrooms are potential to contribute enormously to food value of our habitual diet as they may contribute enormously to the supply of both macroand micro-nutrients in our diet. Nutritive value of mushrooms is attributed to their high content of essential amino acids, vitamins, minerals and low lipid content. Mushroom eaters are generally found to have greater intake levels of most vitamins and minerals and in some cases to consume less alcohol, fat and sodium.

Bangladesh Journal of Nutrition. Vol. 22-23 December, 2009-10. Institute of Nutrition and Food Science, University of Dhaka, Dhaka-1000, Bangladesh.

\footnotetext{
*Author for Correspondence
} 
A greater percentage of mushroom eaters meet the recommended daily allowance(RDA) and daily recommended intake(DRI) for calcium, copper, iron, magnesium, phosphorus, zinc, folate, niacin, riboflavin, thiamin, vitamin A, B6, B12, C, E, energy, carbohydrate, fiber and protein than non-mushroom eaters. Thus they have a better nutrient profile than do those who do not eat mushrooms. ${ }^{1}$

Without doubt, edible mushroom in fresh, cooked or processed forms are nutritionally sound, tasteful food source for most people and can be a significant dietary component for vegetarians ${ }^{2}$. The nutritional value of edible mushrooms compares favorably to that of most vegetables. Within a single mushroom species, the nutrient content varies widely depending on habitat, the growing medium and handling procedures subsequent to harvest. Regular consumption of whole medicinal and edible mushrooms could introduce a functional or medicinal contribution within the individual's diet. Medicinal mushrooms may prevent or treat "lifestyle-related diseases". The extent of the health beneficial effect will depend on the level and regularity of consumption and the relevance of whole fresh medicinal mushrooms and concentrates to the particular disease.

\section{Materials and methods:}

\section{Collection of sample:}

Fresh edible mushrooms were collected from the selling center of "Bangladesh Mushroom Center" and local market at Savar in Dhaka. Mushrooms selected for Present study were Pleurotus ostreatus, Pleurotus sajor-kaju, Pleurotus florida, Pleurotus HK-51 and Calocybe indica. They were selected for the present study as they were available in the market for sale.

\section{Sampling:}

Immediately after procurement from the selling center and local markets, weight of fresh mushrooms (as purchased) were recorded. Then non-edible portions and unwanted wastes or particles (e.g., soil, portion of compost where they were grown, spoiled portion of mushrooms, etc.) if remained were separated and removed. Then total weight of edible fresh mushrooms were recorded. Weighed mushrooms were then cut into small pieces. A small amount(2-5g) in triplicate(from each type of mushroom )were taken for the determination of moisture. Rest of the samples were collected, fresh weight were recorded and samples were dried in an oven at $105^{\circ} \mathrm{C}$ for 4 hours to reduce their moisture content. Weight for dried samples were recorded and drying factors for the samples were determined. Each dried sample was then ground in a mechanical grinder and kept in a air-tight container. Containers with ground samples were kept in a desiccator to inhibit moisture gain 
or loss. Nutrient analysis were accomplished in dry samples and the values were later calculated in terms of fresh weight.

\section{Analytical techniques:}

Moisture, total lipids and ash were determined by following the standard AOAC method $^{3}$. Crude protein was determined by modified Kjeldhal method ${ }^{4}$. Available carbohydrate was estimated indirectly by difference ${ }^{5}$. Dietary fiber was determined by gravimetric method ${ }^{6}$. Total energy was also determined by the calculation of energy values of carbohydrate, fat, protein and crude fiber ${ }^{5}$.

For the estimation of mineral, mushroom sample(1g) was wet digested in a digestion mixture consisting of $18 \mathrm{M}$ sulfuric acid, $12 \mathrm{M}$ Perchloric acid and $16 \mathrm{M}$ nitric acid(0.5:1.0:0.5 by volume ${ }^{7}$. After proper dilution, content of $\mathrm{Zn}, \mathrm{Cu}, \mathrm{Fe}, \mathrm{Ca}$, $\mathrm{Mg}, \mathrm{Mn}, \mathrm{Na}$ and $\mathrm{K}$ were determined by measuring atomic absorption ${ }^{8}$. An appropriate dilution was done with $0.4 \%$ lanthanum(w/w) to overcome ionic interference during the estimation of $\mathrm{Ca}$ and Mg. Estimation of phosphorus was done colorimetrically using the method of Fiske and Subbaraw ${ }^{9}$.

\section{Statistical analysis :}

Mean, S.E.(Standard Error) were determined for all nutrients under present study. Then pair sample t-test of samples were done to determine the significances of inter and intra genus variations. Statistical analysis was accomplished by using Statistical Package for Social Sciences(SPSS/PC; Version12.0; SPSS Inc., Chicago). 
Bangladesh J. Nutr. Vol. 22-23 Dec 2010

Table -1 : Proximate composition of fresh edible mushrooms

\begin{tabular}{|c|c|c|c|c|c|}
\hline \multirow[t]{2}{*}{ Nutrients } & \multicolumn{4}{|c|}{ Oyster } & \multirow{2}{*}{$\begin{array}{c}\text { Milky white } \\
\text { Calocybe indica }\end{array}$} \\
\hline & Pleurotus ostreatus & Pleurotus sajor-caju & Pleurotus florida & Pleurotus HK-51 & \\
\hline Moisture & $\begin{array}{c}88.40^{\mathrm{a}} \pm 0.23 \\
\text { (3) }\end{array}$ & $\begin{array}{c}88.85^{\mathrm{ab}} \pm 0.25 \\
\text { (3) }\end{array}$ & $\begin{array}{c}90.07^{c} \pm 0.13 \\
\text { (3) }\end{array}$ & $\begin{array}{c}89.54^{\mathrm{abcd}} \pm 0.32 \\
\text { (3) }\end{array}$ & $\begin{array}{c}85.95^{\text {abcde }} \pm 1.05 \\
\text { (2) }\end{array}$ \\
\hline Total solids & $\begin{array}{c}11.60^{\mathrm{a}} \pm 0.23 \\
\text { (3) }\end{array}$ & $\begin{array}{c}11.15^{\mathrm{ab}} \pm 0.25 \\
\text { (3) }\end{array}$ & $\begin{array}{c}9.93^{\mathrm{bc}} \pm 0.13 \\
\text { (3) }\end{array}$ & $\begin{array}{c}10.46^{\text {acd }} \pm 0.32 \\
\text { (3) }\end{array}$ & $\begin{array}{c}14.05^{\text {abcde }} \pm 1.05 \\
\text { (2) }\end{array}$ \\
\hline Crude protein & $\begin{array}{c}4.83^{\mathrm{a}} \pm 0.04 \\
\text { (2) }\end{array}$ & $\begin{array}{c}4.20^{\mathrm{ab}} \pm 0.51 \\
\text { (2) }\end{array}$ & $\begin{array}{c}3.29^{\mathrm{abc}} \pm 0.81 \\
\text { (2) }\end{array}$ & $\begin{array}{c}4.23^{\mathrm{abcd}} \pm 0.05 \\
\text { (2) }\end{array}$ & $\begin{array}{c}3.22^{\text {abcde }} \pm 0.17 \\
\text { (2) }\end{array}$ \\
\hline Total lipids & $\begin{array}{c}0.46^{\mathrm{a}} \pm 0.01 \\
\text { (2) }\end{array}$ & $\begin{array}{c}0.55^{\mathrm{ab}} \pm 0.07 \\
\text { (3) }\end{array}$ & $\begin{array}{c}0.41^{\mathrm{abc}} \pm 0.04 \\
\text { (2) }\end{array}$ & $\begin{array}{c}0.43^{\mathrm{abcd}} \pm 0.01 \\
\text { (3) }\end{array}$ & $\begin{array}{c}1.05^{\mathrm{ce}} \pm 0.03 \\
\text { (3) }\end{array}$ \\
\hline Available $\mathrm{CHO}$ & 4.28 & 4.65 & 4.37 & 4.24 & 6.38 \\
\hline Dietary fiber & $\begin{array}{c}0.63^{\mathrm{a}} \pm 0.02 \\
\text { (2) }\end{array}$ & $\begin{array}{c}0.64^{\mathrm{ab}} \pm 0.06 \\
\text { (2) }\end{array}$ & $\begin{array}{c}0.59^{\mathrm{abc}} \pm 0.01 \\
\text { (2) }\end{array}$ & $\begin{array}{c}0.58^{\mathrm{abcd}} \pm 0.05 \\
\text { (3) }\end{array}$ & $\begin{array}{c}1.11^{\text {bde }} \pm 0.02 \\
\text { (2) }\end{array}$ \\
\hline Ash & $\begin{array}{c}1.41^{\mathrm{a}} \pm 0.03 \\
\text { (3) }\end{array}$ & $\begin{array}{c}1.12^{\mathrm{ab}} \pm 0.00 \\
\text { (3) }\end{array}$ & $\begin{array}{c}1.27^{\mathrm{C}} \pm 0.02 \\
\text { (3) }\end{array}$ & $\begin{array}{c}0.98^{\mathrm{d}} \pm 0.02 \\
\text { (3) }\end{array}$ & $\begin{array}{c}2.30^{\text {abcde }} \pm 0.73 \\
\text { (2) }\end{array}$ \\
\hline $\begin{array}{l}\text { Calorie } \\
\text { (Kcal/100gEP) }\end{array}$ & 41.80 & 41.84 & 35.51 & 38.91 & 50.03 \\
\hline
\end{tabular}

Results were expressed as mean $\pm \mathrm{SE}$ and as g/100g EP. Figure in the parenthesis indicates the number of sample analyzed. Values in the same row not sharing common superscript letter(s) are significantly ( $\mathrm{P} \leq 0.05$ ) different .

Table- 2: Zinc, copper ,iron and manganese content in different varieties of edible mushrooms

\begin{tabular}{|c|c|c|c|c|c|}
\hline \multirow[t]{2}{*}{ Minerals } & \multicolumn{4}{|c|}{ Oyster } & \multirow{2}{*}{\begin{tabular}{|c|} 
Milky white \\
Calocybe indica
\end{tabular}} \\
\hline & Pleurotus ostreatus & Pleurotus sajor-caju & Pleurotus florida & Pleurotus HK-51 & \\
\hline Zinc & $\begin{array}{c}1.10^{\mathrm{a}} \pm 0.04 \\
\text { (4) }\end{array}$ & $\begin{array}{c}0.68^{\mathrm{ab}} \pm 0.08 \\
\text { (2) }\end{array}$ & $\begin{array}{c}0.65^{\mathrm{bc}} \pm 0.05 \\
\text { (3) }\end{array}$ & $\begin{array}{c}1.24^{\mathrm{abc}} \pm 0.07 \\
\text { (4) }\end{array}$ & $\begin{array}{c}0.78^{\text {abce }} \pm 0.05 \\
\text { (3) }\end{array}$ \\
\hline Copper & $\begin{array}{c}0.18^{\mathrm{a}} \pm 0.00 \\
\text { (3) }\end{array}$ & $\begin{array}{c}0.37^{\mathrm{ab}} \pm 0.05 \\
\text { (3) }\end{array}$ & $\begin{array}{c}0.14^{\mathrm{abc}} \pm 0.01 \\
\text { (2) }\end{array}$ & $\begin{array}{c}0.20^{\text {abcd }} \pm 0.02 \\
\text { (3) }\end{array}$ & $\begin{array}{c}0.91^{\mathrm{e}} \pm 0.05 \\
\text { (3) }\end{array}$ \\
\hline Iron & $\begin{array}{c}1.76^{\mathrm{a}} \pm 0.23 \\
\text { (3) }\end{array}$ & $\begin{array}{c}0.94^{\mathrm{ab}} \pm 0.06 \\
\text { (2) }\end{array}$ & $\begin{array}{c}0.81^{\mathrm{abc}} \pm 0.00 \\
\text { (2) }\end{array}$ & $\begin{array}{c}1.40^{\text {abcd }} \pm 0.12 \\
\text { (2) }\end{array}$ & $\begin{array}{c}1.81^{\text {acde }} \pm 0.07 \\
\text { (3) }\end{array}$ \\
\hline Manganese & $\begin{array}{c}0.27^{\mathrm{a}} \pm 0.06 \\
\text { (3) }\end{array}$ & $\begin{array}{c}0.19^{\mathrm{ab}} \pm 0.05 \\
\text { (3) }\end{array}$ & $\begin{array}{c}0.17^{\mathrm{abc}} \pm 0.00 \\
\text { (3) }\end{array}$ & $\begin{array}{c}0.24^{\text {abcd }} \pm 0.05 \\
\text { (3) }\end{array}$ & $\begin{array}{c}0.53^{\mathrm{ae}} \pm 0.04 \\
\text { (3) }\end{array}$ \\
\hline
\end{tabular}

Results were expressed as mean $\pm \mathrm{SE}$ and as mg/100g EP. Figure in the parenthesis indicates the number of sample analyzed. Values in the same row not sharing common superscript letter(s) are significantly ( $\mathrm{P} \leq 0.05)$ different . 
Table3:Calcium, magnesium and phosphorus content in different varieties of edible mushrooms

\begin{tabular}{|c|c|c|c|c|c|}
\hline \multirow[t]{2}{*}{ Minerals } & \multicolumn{4}{|c|}{ Oyster } & \multirow{2}{*}{$\begin{array}{l}\text { Milky white } \\
\text { Calocybe indica }\end{array}$} \\
\hline & Pleurotus ostreatus & Pleurotus sajor-caju & Pleurotus florida & Pleurotus HK-51 & \\
\hline Calcium & $\begin{array}{c}0.19^{\mathrm{a}} \pm 0.03 \\
\text { (3) }\end{array}$ & $\begin{array}{c}0.16^{\mathrm{ab}} \pm 0.00 \\
\text { (2) }\end{array}$ & $\begin{array}{c}0.15^{\mathrm{abc}} \pm 0.05 \\
\text { (2) }\end{array}$ & $\begin{array}{c}0.12^{\mathrm{abcd}} \pm 0.06 \\
\text { (2) }\end{array}$ & $\begin{array}{c}0.58^{\text {cde }} \pm 0.03 \\
\text { (2) }\end{array}$ \\
\hline Magnesium & $\begin{array}{c}37.39^{\mathrm{a}} \pm 6.25 \\
\text { (2) }\end{array}$ & $\begin{array}{c}30.06^{\mathrm{ab}} \pm 2.06 \\
\text { (3) }\end{array}$ & $\begin{array}{c}27.26^{\mathrm{abc}} \pm 4.67 \\
\text { (2) }\end{array}$ & $\begin{array}{c}35.86^{\mathrm{abcd}} \pm 0.24 \\
\text { (3) }\end{array}$ & $\begin{array}{c}51.21^{\text {abcde }} \pm \\
13.67 \\
\text { (2) }\end{array}$ \\
\hline Phosphorus & $\begin{array}{c}41.13^{\mathrm{a}} \pm 0.72 \\
\text { (2) }\end{array}$ & $\begin{array}{c}62.10^{b} \pm 0.126 \\
\text { (2) }\end{array}$ & $\begin{array}{c}22.20^{c} \pm 0.47 \\
\text { (2) }\end{array}$ & $\begin{array}{c}47.95^{\mathrm{d}} \pm 1.03 \\
\text { (2) }\end{array}$ & $\begin{array}{c}61.83^{\text {be }} \pm 0.73 \\
\text { (2) }\end{array}$ \\
\hline
\end{tabular}

Results were expressed as mean $\pm \mathrm{SE}$ and as $\mathrm{mg} / 100 \mathrm{~g}$ EP.Figure in the parenthesis Indicates the number of sample analyzed. Values in the same row not sharing common superscript letter(s) are significantly ( $\mathrm{P} \leq 0.05)$ different .

Table-4: Sodium and potassium content in different varieties of edible mushrooms

\begin{tabular}{|l|c|c|c|c|c|}
\hline \multirow{2}{*}{ Minerals } & \multicolumn{4}{|c|}{ Oyster } & Milky white \\
\cline { 2 - 6 } & Pleurotus ostreatus & Pleurotus sajor-caju & Pleurotus florida & Pleurotus HK-51 & Calocybe indica \\
\hline Sodium & $5.31^{\mathrm{a}} \pm 0.27$ & $7.51^{\mathrm{b}} \pm 0.24$ & $3.18^{\mathrm{c}} \pm 0.12$ & $7.14^{\mathrm{bd}} \pm 0.08$ & $37.23^{\mathrm{e}} \pm 0.79$ \\
& $(4)$ & $(4)$ & $(4)$ & $(4)$ & $(4)$ \\
\hline Potassium & $35.17^{\mathrm{a}} \pm 0.79$ & $48.68^{\mathrm{b}} \pm 0.12$ & $19.83^{\mathrm{c}} \pm 0.69$ & $50.75^{\mathrm{bd}} \pm 4.03$ & $197.24^{\mathrm{e}} \pm 11.61$ \\
& $(4)$ & $(4)$ & $(4)$ & (4) & $(4)$ \\
& & & &
\end{tabular}

Results were expressed as mean $\pm \mathrm{SE}$ and as $\mathrm{mg} / 100 \mathrm{~g}$ EP. Figure in the parenthesis Indicates the number of sample analyzed. Values in the same row not sharing common superscript letter(s) are significantly ( $\mathrm{P} \leq 0.05)$ different .

\section{Results and Discussion:}

Mushrooms generally are classified into four groups: edible mushrooms, medicinal mushrooms, poisonous mushrooms and magic or hallucinogenic mushrooms. Edible mushrooms are an ideal healthy foods. They may contribute enormously to the supply of both macro and micro nutrients in our diet. They are considered to be the potential source of carbohydrates, proteins, fat, and minerals. All of which contribute to the food value. 
The present study depicts the content of moisture, total solids, crude protein, total lipids, available carbohydrates, dietary fiber, total ash, calorie values and minerals( $\mathrm{Zn}, \mathrm{Cu}, \mathrm{Fe}, \mathrm{Ca}, \mathrm{Mg}, \mathrm{Mn}, \mathrm{P}, \mathrm{Na}$ and $\mathrm{K}$ ) in five species of edible mushrooms. Species selected for analysis were Pleurotus ostreatus, Pleurotus sajor-caju, Pleurotus florida, Pleurotus HK-51 belonging to the familyPleurotaceae and genus - Pleurotus and Calocybe indica belonging to the family - Tricholomataceae and Genus - Calocybe.

Mushrooms are generally high in their moisture content, the content being approximately $90 \%$ of their fresh weight. In present study, moisture content in mushrooms was found to be in a range of $85.95-90.07 \mathrm{~g} \%$. Total solid content was found to be relatively high(14.05g\%) in Calocybe indica and low(9.93 g\%) in Pleurotus florida. Mushrooms are considered to be a good source of digestible proteins. In present study, crude protein content in mushrooms was found to be in a range of $3.22-4.83 g \%$. Crude protein content was found to be relatively high(4.83g\%) in Pleurotus ostreatus and low(3.22g\%) in Calocybe indica, though the content did not differ significantly between the varieties. Fresh mushrooms usually contain less fat, the amount being $1-8 \%$ of dry weight ${ }^{2}$. In present study, total lipids content in mushrooms was found to be in a range of $0.41-1.05 \mathrm{~g} \%$. Mushrooms have no cholesterol and are virtually low in fat. All fresh mushrooms are free of trans fats. The fat content of edible mushrooms consists mostly of unsaturated fatty acids, which are less hazardous to the health than the saturated fatty acids of animal fats ${ }^{2}$. Available carbohydrates are the second major nutrient component of mushrooms, amounting to an average of $4.2 \%{ }^{10}$. In present study, available carbohydrates content in mushrooms was found to be in a range of 4.24$6.37 \mathrm{~g} \%$. Available carbohydrate content in oyster varieties compared well, while the content was relatively high(6.38g\%) in Calocybe indica. Mushrooms are valuable sources of dietary fibre ${ }^{12}$. Dietary fiber content of mushrooms, in present study, was found to be in a range of $0.58-1.11 \mathrm{~g} \%$. Dietary fiber content in oyster varieties was found to be in a comparable range and did not differ significantly, while the content in Calocybe indica appeared to be relatively high(1.11g\%) as compared to oyster varieties. Total carbohydrates content of mushrooms was found to be in a range of 4.82-7.48g \%. Total carbohydrates content in mushrooms was found to be relatively high (7.48 g\%) in Calocybe indica and low (4.82 g \%) in Pleurotus HK-51. Calorie value of mushrooms, in present study, was found to be in a range of $35.51-50.03 \mathrm{Kcal} / 100 \mathrm{~g}$. Calorie value was found to be highest (50.03 kcal/100g) in Calocybe indica and lowest (35.51 Kcal/100g) in Pleurotus florida . Mushrooms are regarded as low fat calorie foods. This low calorie value is attributable to the content of high fiber, low fat, no cholesterol and no free fatty acids in mushroom. ${ }^{2,22}$ In this study, we found that the contents of moisture, crude protein, total lipids, available carbohydrates, dietary fiber, total ash and calorie were in a good agreement with the values reported in some previous studies. ${ }^{12,15 \text {, }}$ 
16,17,18 It is important to be noted that Calocybe indica which belongs to another genus - Calocybe is relatively rich in total solids, total lipids, available carbohydrates, dietary fiber, total carbohydrates, total energy, total ash, copper, iron, calcium, phosphorus, magnesium, manganese, sodium, and potassium as compared to all varieties of Pleurotus . Calocybe indica was low only in moisture as compared to Pleurotus varieties.

Zinc, copper, iron and manganese content in mushrooms were found to be in the ranges of $0.65-1.24,0.14-0.91,0.94-1.81$ and $0.17-0.53 \mathrm{mg}$ per $100 \mathrm{~g}$ of fresh edible portion respectively while calcium, magnesium and phosphorus content were in the ranges of $0.12-0.58,27.26-51.21$ and 22.2- $62.1 \mathrm{mg}$ per $100 \mathrm{~g}$ of fresh edible portion respectively. The value of sodium and potassium content in mushrooms were found to be in the ranges of $3.18-37.23$ and $19.83-197.24 \mathrm{mg}$ per $100 \mathrm{~g}$ of fresh edible portion respectively. Values of copper ${ }^{13,14,15,17}$, sodium ${ }^{13,14,15,17}$ and iron ${ }^{17,18}$ were in a good agreement with some of the previous studies on mushroom where as values of zinc, calcium, magnesium, manganese potassium and phosphorus were low as compared with previous studies ${ }^{13,14,15,17,18,20,21}$. Amongst the Pleurotus varieties of mushrooms, Pleurotus ostreatus stands out to be relatively rich in crude protein, zinc and iron while Pleurotus sajor-caju appears to be relatively rich in phosphorus,sodium and potassium. Pleurotus florida stands out to be high in moisture. Pleurotus HK-51 is relatively rich in zinc, iron, sodium and potassium.

The present study reveals an inter and intra genus variation in nutrient content of mushrooms. Despite the differences in their nutrient content, the overall nutritive picture of these mushrooms appears to be quite sound. They hold out a promise to contribute significantly to the intake of micro-nutrients amongst our people. So, the mushrooms should surely be incorporated into our diets more frequently in order to improve the quality of our habitual diets. This endeavor will certainly improve our micronutrient situation, improving the overall health and ensuring the general wellbeing of the people.

\section{References:}

1. Stamets P, Growing Gourmet and Medicinal Mushrooms, Berkeley/Toronto: Ten Speed Press, 2000.

2. Breene W, Nutritional and medicinal value of speciality mushrooms, Journal of Food Production, 1990; 53:883-894.

3. AOAC (Association of Official Analytical Chemist), Official Methods of Analysis, $15^{\text {th }}$ edition, Washington DC, 1984.

4. Bradstreet RB, The Kjeldahl Method for organic Nitrogen, Academic Press, New York, 1965.

5. Food and Agriculture Organization, Food and Nutrition paper, 77 , ISSN 0254-4725 . Food energy-methods of analysis and conversion factor, Report of the technical workshop, Rome, 2002 Dec 3-6, FAO, 2003. 
6. Official Methods of Analysis, $15^{\text {th }}$ edition, Method 991.43, $3^{\text {rd }}$ supplement, AOAC (Association of Official Analytical Chemist), Washington DC, 1992; 136-138.

7. Davis NT, Hillary R, An evaluation of the phytate, zinc, copper, iron and manganese contents and zinc availability from soya-based textured vegetable-protein, meat substitutes or meat extenders, British Journal of Nutrition, 1979; 41:579-89.

8. Milner BA, Whitside PJ, An Introduction to Atomic Absorption Spectrophotometry, Pye Unicam Ltd., York Street, Cambridge, England, CBI-2px; 1981;75-78 .

9. Fiske and Subba Row, Estimation of phosphorus, J. Biol Sci. 1925; 66:375

10. Fukushima $\mathrm{M}$ et al, LDL receptor mRNA in rats is increased by dietary mushroom (Agaricus bisporus) fibre and sugar beet fibre, Journal of Nutrition 2000; 130: 151-2156.

11. States of Mushroom Nutrition Research(SMNR),2004, Mushroom Council 20032004(www.mushroomcouncil.org).

12. Chandravadana MV, Vekateshwarlu G, Bujji Babu CS, Roy TK, Shivashankara K, Meera Pandey, Tewari RP , Selvaraj Y,2005, Volatile flavour components of dry milky mushrooms (Calocybe indica), Flavour and Fragrance Journal, 20(6):715-717

13. Lebensm Z,1994, The copper , manganese and zinc content of some edible mushrooms. Med Gen Mede Journal,198(6): 469-72, ISSN: 0044-3026.

14. Mattila P, Konko K, Eurola M, Pihlava JM, Astola J, Vahteristo L, Hietaniemi V, Kumpulainen J, Valtonen M, Piironen V, 2001, Contents of vitamins, mineral elements, and some phenolic compounds in cultivated mushrooms, J Agric Food Chem , 49(5): 2343-8.

15. M.Sc. Thesis,1998, Nutritional analysis of edible mushrooms in different developmental stages, Exam roll: 3809 Session:1997-1998, INFS(Institute of nutrition and food science ), DU.

16. Mushroom Bureau, 2004( www.mushroom-uk.com).

17. Pehrsson PR, Haytowitz DB, Holden JM, 2003,The USDA's National Food and Nutrient Analysis Program: Update 2002, J Food Comp. Anal. 16(3): 331-341 .

18. Prasad Padmaja,1994, Let the mushrooms mushroom, Nutrition 31, 1 , 3 , National Institute of Nutrition, ICMR, Hyderabad, ISSN: 500-007, In : Food Science; Srilaskshmi B; 3 rd edition; New age international publication, India, PP: 197.

19. Berkeley CA, 2003, Third National Health and Nutrition Examination Survey of 20,050 adults, U.S.A .

20. Murphy EW, Criner PE, and Gray BC,1975, Comparison of methods for determining retention of nutrients in cooked foods, Journal of Agriculture and Food chemistry, 23:1153.

21. Patrabansh S, Madan M, 1999, Mineral content of the fruiting bodies of Pleurotus sajor-caju (FR.), Jn: Acta Biotechnologica, 19(2): 101-109 .

22. Chang ST, 1991, Cultivated mushrooms, In: Handbook of Applied Mycology, PP 3: 221-240. 